Vito Flaker

Faculty for Social Work

University of Ljubljana, Slovenia

\title{
INSTITUTIONS AS A LETHAL WEAPON: THE CASE OF SLOVENIA IN THE FIRST WAVE OF THE COVID-19 EPIDEMIC
}

\begin{abstract}
The Covid-19 epidemic has most affected old people, not those who live at home - but those in old age homes. In Slovenia, as many as four-fifths of those deceased in the epidemic were residents of these institutions. The analysis shows that the essential moment of infection is institutionality, not age, that it is in this sense almost an institutional epidemic. The make-up of total institutions presents a significantly higher risk of transmission of infection - due to increased human concentration and increased frequency of contacts, but also because of the institutional structure and ethos, which objectify residents and deprive residents of the power of action. The deceased residents can be seen as (passive) victims not only of the virus, but also of the institutional nature of the organisation of care (prevailing in Slovenia). This was neglected in the debate so far, the measures introduced did not allow transfer to community care, which would provide residents with the level of safety comparable to the population at large, such services allowing a greater degree of self-isolation and control of contacts. The deceased residents are victims of a delay in deinstitutionalisation and in in-

troduction of a potent, community based long-term care. These are the pressing tasks for the future, if we are to ensure at least safety for old people, and with it a life worth living.

Keywords: corona virus, old age homes, total institutions, deinstitutionalisation, long-term care

\section{Introduction}

We knew the virus was perilous for the old and very sick, however, it soon became apparent that the issue is not only the "age" but also the institutions hosting old people. However obvious the problem of concentration of (old) people in one place, the discourse on the old people and the epidemics in old age homes failed to mention the fact that old age homes are basically total institutions. With this omission the debate steered away from the chronic problem of the high rate of institutionalisation in Slovenia (more than 20.000 residents in 2 million population) and avoided the discussion of the necessity of introduction of the long-term care, as the way of replacing the institutional capacities and with it - providing a safer care.
\end{abstract}


Some see old age homes as places where old people usually are, and have taken for granted that the epidemics strikes in the places where old people live. Others have, rightly so, complained about the staff shortage in these facilities. A dilemma arose, whether the infected old people should remain in old age homes or should they be transferred to hospitals - as the old age homes do not have personnel trained in working with the infection. A legitimate concern and criticism on the privatisation of institutional care was raised (although as we will see in Slovenia this was not an issue related to epidemics). Discourse has therefore touched on the issue of the old age homes, but did not enter into the merit of the issue - the concentration of people and existence of total institutions. (Perhaps the perception was quite the opposite - that we are lucky to have them - during an epidemic.)

The controversy of the old age homes broke out only in the time the epidemic was subsiding (coinciding with the time of this review of the data), after an interview with an ex-minister of health, Dušan Keber in Mladina on $16^{\text {th }}$ May (Jager, 2020b). The interview did not only bring to the attention the large number of deaths in old age homes, but also denounced the phenomenon of ageism during the epidemic (deprivation for proper treatment by failing to transfer residents to the hospitals), pointing to the fact that the old age homes are not equipped to deal with the disease. However, this critique still silently embraced the axiom of the necessity of such establishments and did not problematize their very existence and the highest institutionalisation rate in Slovenia nor the lack of relevant community services and community care, which, in particular during the epidemic, could more effectively and safely, as well as more humanly, respond to people's distress.

Hence, we will look at the state of the art and to try to understand the dynamics of the events primarily through the aspect of institutionalisation as a risk factor. For now, we can do this primarily by reviewing relevant data ${ }^{1}$ on the spread infection, identifying relationships between age, institutions, (confirmed) infections and victims of infections. And then we will try to explain these by the theory of total institutions and by anecdotal reports from the field.

\section{Virus is transmitted by anybody - old are dying}

Daily provided data on confirmed infections (CI) show that the infection was spreading quite evenly across the age groups while the mortality rate is not. In fact, at that time, mortality was noted in Slovenia almost exclusively in older age groups - 100 of 104 deceased were older than 65 and 84 were over 75 years. On the other hand, the share of all confirmed infected in the age group over 65 years was $31.33 \%$, and $22.46 \%$ for the group above 75 years.

All data, unless otherwise stated, are the data of the COVID-19 tracker Https://covid-19.sledilnik. org/stats per day on $17^{\text {th }}$ May 2020 and were valid for $16^{\text {th }}$ May. 
Table 1: Rate of confirmed infections and mortality by age

\begin{tabular}{|c|c|c|c|c|c|c|c|c|}
\hline \multirow[t]{2}{*}{ Age } & \multirow[t]{2}{*}{ CI M } & \multirow[t]{2}{*}{$\mathrm{F}$} & \multirow[t]{2}{*}{$\Sigma$} & \multirow{2}{*}{\multicolumn{2}{|c|}{$\begin{array}{l}\% \text { of the } \\
\text { population }\end{array}$}} & \multicolumn{3}{|c|}{ Deceased } \\
\hline & & & & & & M & $\mathrm{F}$ & $\Sigma$ \\
\hline Over 85 & 36 & 134 & 170 & 0,264 & 0,365 & 14 & 44 & 58 \\
\hline $75-84$ & 72 & 87 & 159 & 0,132 & 0,106 & 15 & 11 & 26 \\
\hline $65-74$ & 72 & 60 & 130 & 0,071 & 0,053 & 10 & 5 & 15 \\
\hline $55-64$ & 117 & 102 & 217 & 0,079 & 0,069 & 2 & 0 & \\
\hline $45-54$ & 108 & 135 & 243 & 0,070 & 0,092 & 1 & 1 & \\
\hline $35-44$ & 90 & 112 & 202 & 0,055 & 0,076 & & & \\
\hline $25-34$ & 91 & 113 & 204 & 0,068 & 0,092 & & & \\
\hline $15-24$ & 42 & 60 & 102 & 0,042 & 0,064 & & & \\
\hline $5-14$ & 15 & 12 & 27 & 0,014 & 0,012 & & & \\
\hline $0-4$ & 4 & 4 & 8 & 0,008 & 0,008 & & & \\
\hline total above 65 & 180 & 281 & 459 & & & 39 & 60 & 99 \\
\hline total above 75 & 108 & 221 & 329 & & & 29 & 55 & 84 \\
\hline
\end{tabular}

Source: COVID-19 tracker Https://covid-19.sledilnik.org/stats

At first glance on the rate of (confirmed) infections it could be assumed that the older segment of population was afflicted more. However, when we look in detail, we see that the percentage relative to the population in this group with minor deviations is relatively regular for all groups under 75 years, significantly lower for children and significantly higher for the oldest (two to three times as much).

The higher number of confirmed infections in the oldest groups can be attributed to a greater visibility (more obvious symptoms, manifestation of the infection more dramatic) and a greater observability (intense monitoring and observation, more tests). Two additional hypothetical explanations can be postulated. One is that old people are more exposed (by their social position) or more susceptible to infection, i.e. that there could exist physiological mechanism of easier contracting of infection (hardly believable). ${ }^{2}$

The first two hypotheses point to the distortion of the sample, to a necessarily biased gaze, that there are hidden - not visible and not observable - cases and that the infection was in fact more evenly distributed in the population. The other two interpretations, however, assume the actual spread of infection was significant-

\footnotetext{
2 Here we are referring to the mechanisms of contracting the infection not the disease. The immunity hides the infection, obscures its visibility and is not an issue of transmission to a single person. The issue of transmission would be e.g. the state of mucus related to age. For lay persons such a hypothesis is of primarily theoretical nature and almost unbelievable, and even if true, it would explain only a margin of events.
} 
ly different in the old age groups - mainly due to increased exposure.

On the other hand, almost exclusive mortality of old people can be explained easily physiologically, by the course of the disease. Greater numbers of deaths in older age groups could therefore be attributed to lower resilience (more chronic diseases, e.g. heart failure, diabetes mellitus, high blood pressure etc.). Still, a higher incidence of fatal outcomes can be attributed to the greater exposure.

The greater exposure of old people is, of course, not due to their greater mobility or more numerous contacts with more opportunities for infection. Quite contrary, old people have on average fewer contacts and are less mobile. However, this is true for old people living at home (these may even be less exposed than the general population). Those who are in the institutions, however, have almost certainly on average more contacts than people who have, to fend off the epidemic, resorted to self-isolation. Exposure of the old is in concentration of people in the institutions.

\section{Institutions - the focal points of infections}

The relationship between the institutions and the contamination rate is evident also in the statistical data. By $16^{\text {th }}$ May $^{3}$, there were 458 confirmed infections in old age homes, $31.26 \%$ of all confirmed infected in the country. Of these, 137 were

This was approximately also the time when the first wave of infection has subsided. employees and 321 residents $(21.91 \%$ or good fifth of all confirmed infected in the country - which is twenty times as many as the share of the institutions' residents in the population). If we add 166 confirmed infected in health sector (personnel, not patients ${ }^{4}$ ), there were 624 or $42.59 \%$, almost half, of all confirmed infected in Slovenia, in both types of institutions.

Based on these figures, we can affirm that the corona virus phenomenon is closely related to institutions, since a good part of the infections can be explained by infected persons either living or working in institutions. As in the case of age differences, one part of this "statistical" phenomenon can be attributed to the collection of data - i.e. visibility and observability - a more pronounced symptoms, and more attention and testing than outside the institutions.

The mortality data are among the data sets the least contaminated with "sampling skewness" - of visibility and observability. Failing to attribute a fatal outcome to this disease, may occur in statistics in the early stages of the epidemic, but when attention is directed to the disease, we can assume that the interval of such error is significantly narrower. Data on deceased in old age homes were, unfortunately, not available until the end of the first wave of epidemic. $^{5}$

The data on how many patients got infected in hospitals are not available.

$5 \quad$ These were publicly reported only after $15^{\text {th }}$ May, after the interview with Dr. Keber. By coincidence this was the time when work on the Slovene version of this paper commenced. Since there 


\section{Old age homes - almost exclusive territory of corona}

The infection was recorded in six old age homes in Slovenia, i.e. $5 \%$ of all such establishments (125). ${ }^{6}$ The number may seem small, it is only a "handful" of institutions, and however, it is significantly higher than the level of infection in the

were no data on number of deceased available, an estimate had to be reconstructed on the basis of data of confirmed infections in old age homes (which were available) and the data of confirmed infections by age groups and municipalities. The line of text advertently follows this line of thought. (The estimate was confirmed a day or two later).

6 Apparently, there were a few more homes (three to four) apart those detected in the official statistics (Kovač, 2020). But given small numbers, the figures we quote warrant our argumentation sufficiently. whole population, which was expected to be $2 \%$ at the time.

Almost all confirmed institutional infections $(441-96 \%)$ were registered in these six institutions. However, the degree of contamination in these six homes varies considerably. In two homes (Ljutomer, Šmarje) more than half, almost two thirds, of residents and almost half of the staff contracted the infection. In another two homes the infection rate was still significant - infection was confirmed with almost a third of residents and almost a fifth of staff in Metlika, while in Horjul just over a fifth of residents and a tenth of staff were infected. While in the other two institutions (Bokalci and Naklo) the epidemic has only made a marginal appearance.

The contaminated homes were quite diverse in size, among them there was a

Table 2: Number of confirmed infections in old age home respective to the size of establishment

\begin{tabular}{|l|r|r|r|r|r|r|r|r|r|}
\hline Institution & $\Sigma$ & $\begin{array}{r}\text { CI resi- } \\
\text { dents }\end{array}$ & $\begin{array}{r}\text { CI } \\
\text { staff }\end{array}$ & $\begin{array}{r}\text { CI res. } \\
(\%)\end{array}$ & $\begin{array}{r}\text { CI } \\
\text { staff } \\
(\%)\end{array}$ & $\begin{array}{r}\text { No. } \\
\text { res. }\end{array}$ & $\begin{array}{r}\text { No. } \\
\text { staff }\end{array}$ & res/ staff & Rank \\
\hline Šmarje & 181 & 124 & 57 & 57,94 & 46,72 & 214 & 122 & 1,754098 & 100. \\
\hline Ljutomer & 139 & 99 & 40 & 63,87 & 45,45 & 155 & 88 & 1,761364 & $71,5$. \\
\hline Metlika & 71 & 53 & 18 & 30,81 & 18,37 & 172 & 98 & 1,755102 & $78,5$. \\
\hline Horjul & 26 & 21 & 5 & 21,88 & 9,09 & 96 & 55 & 1,745455 & 28. \\
\hline Bokalci & 20 & 17 & 3 & 4,50 & 1,40 & 378 & 215 & 1,758140 & 123. \\
\hline Naklo & 4 & 2 & 2 & 4,35 & 7,69 & 46 & 26 & 1,769231 & 9. \\
\hline $\begin{array}{l}\text { Total (selected } \\
\text { homes) }\end{array}$ & $\mathbf{4 4 1}$ & $\mathbf{3 1 6}$ & $\mathbf{1 2 5}$ & 29,78 & 20,70 & $\mathbf{1 0 6 1}$ & $\mathbf{6 0 4}$ & & \\
\hline $\begin{array}{l}\text { other homes } \\
\text { with CI }\end{array}$ & 17 & 5 & 12 & & & & & & \\
\hline Total & 458 & 321 & 137 & & & $\mathbf{2 0 4 3 1}$ & 11646 & & \\
\hline
\end{tabular}

Source: COVID-19 tracker Https://covid-19.sledilnik.org/stats 
very small ( $1^{\text {st }}$ quintile, Naklo), small ( $2^{\text {nd }}$ quintile - Horjul), larger (limit value of $3^{\text {rd }}$ quintile - Ljutomer), large ( $4^{\text {th }}$ quintile - Metlika) and two were among the largest $\left(5^{\text {th }}\right.$ quintile Šmarje (limit value) and Bokalci). All, but one, were public institutions, and they all have a very similar rate of staff and residents. Their common characteristic could be that they are situated on the periphery, all except the Bokalci (Ljubljana), are situated in small townships.

A surprising feature of these data is that the number of confirmed infections of residents is consistently higher than of employees (except for Naklo, where numbers are small for both categories). One would expect higher figures among the staff since they bring the infection and are due to their mobility more exposed to contacts etc.

The total number of residents with confirmed infection was 321 , while in the total population the number of confirmed infections for the age group above 65 year was 459. Confirmed infections in care homes therefore account for $70 \%$ (69.93\%) of confirmed infected people in the age group above 65 years. However, the residents of old age homes are in average significantly older and statistics of confirmed infections show that in the age group over 75 years there were only eight (8) cases more than the number of people confirmed infected in the institutions, This means that old age homes residents constitute $96.5 \%$ of the confirmed infections in the age group over 75 .
Exposure of old people to the infection can be therefore accounted for primarily, or almost exclusively to the residence in the old age homes.

Mortality statistics in care homes (initially not accessible) show that at least 86 residents of nursing homes departed, which is more than $80 \%(81.13 \%)$ of the total number of people who died of the disease. The institutional background therefore explains more than four fifths of fatal outcomes of this disease; in the age group over 75 almost all of them (86).

The institutional background is therefore the absolute correlate, if not the cause, of mortality for old people - and for the whole population the dominant one.

\section{The geographical distribution of mortality is institutional}

The next source of widely available data was the epidemiological situation in municipalities. When we observe the map of infection and mortality rates, it is at first sight clear that the municipalities, in which the respective homes are situated, stand out. There, the level of confirmed infections is higher; on the map, which represents the geographical distribution of mortality, with a few exceptions (see table in the appendix), everywhere else (except Ljubljana) is a blank area.

This is confirmed by the numerical comparison. The number of confirmed infections is almost identical (except for Ljubljana) to the number of confirmed 


\section{Figure 1: Number of confirmed infections by municipalities in Slovenia}

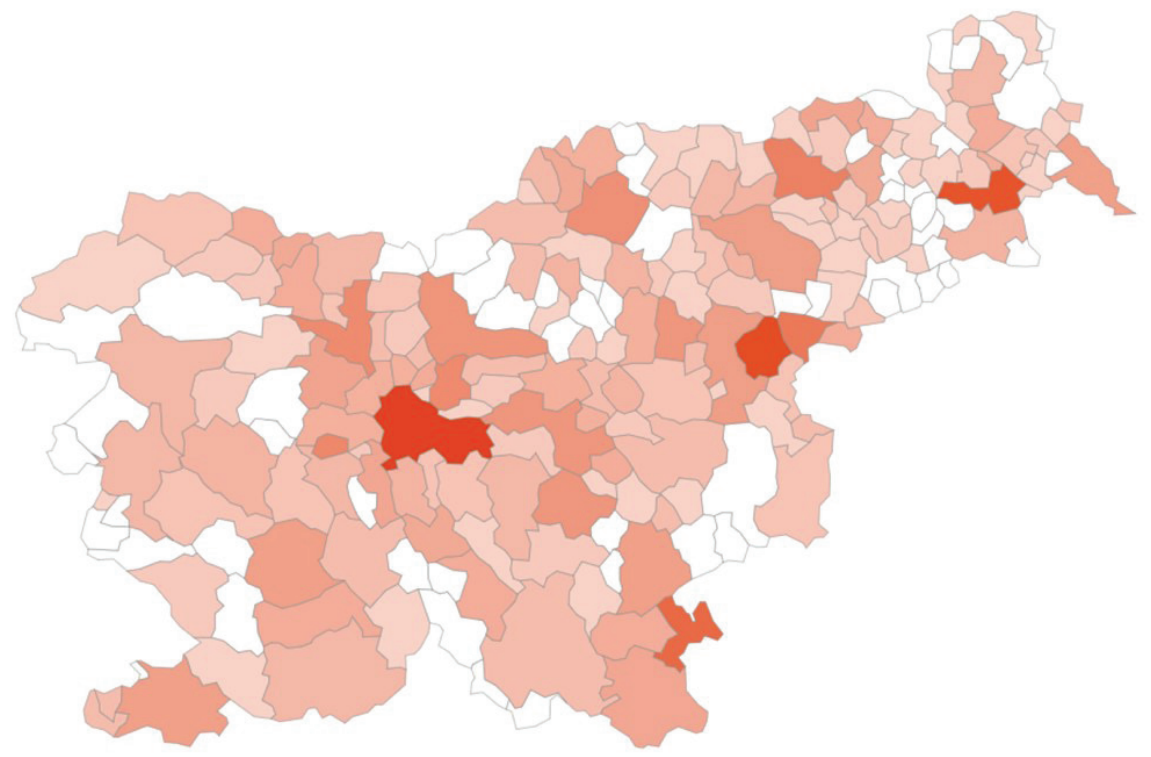

Source: COVID-19 tracker Https://covid-19.sledilnik.org/stats

Figure 2: Mortality rate relative to number of municipality inhabitants in Slovenia

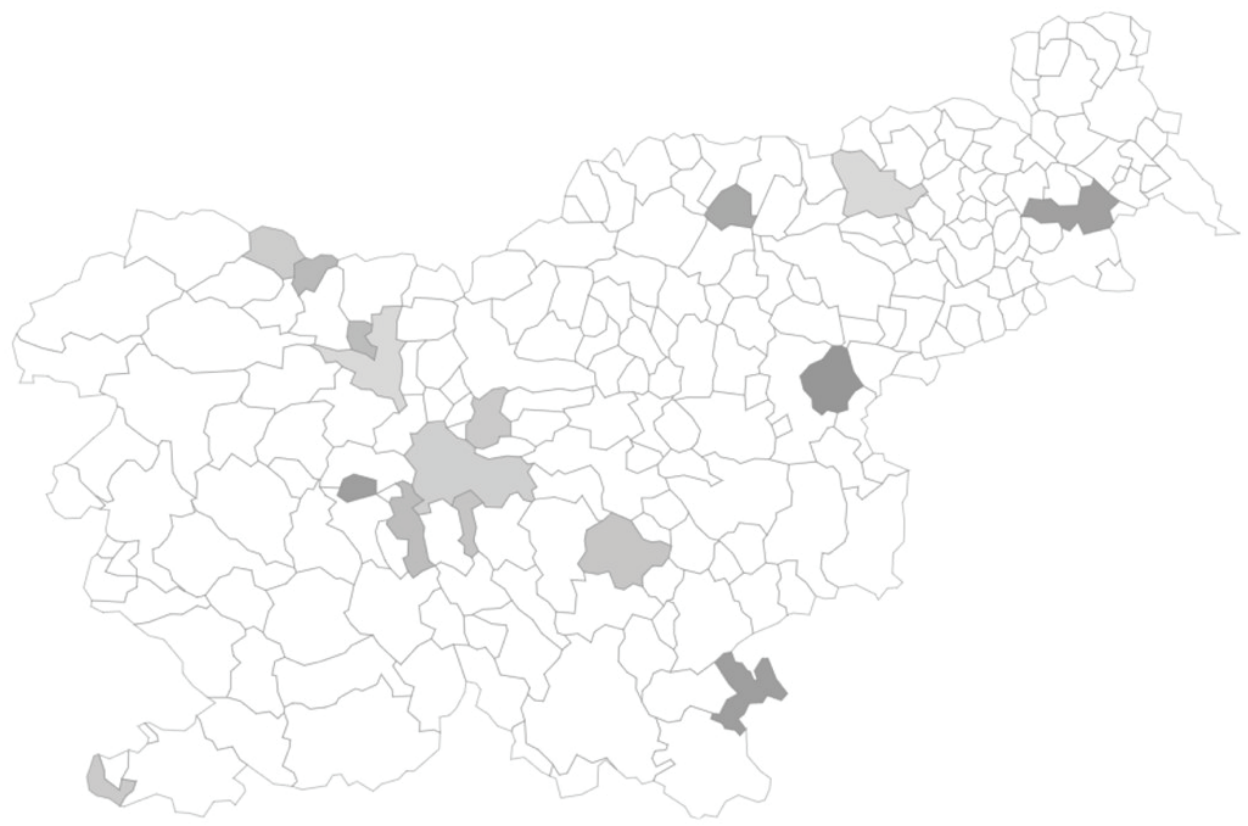

Source: COVID-19 tracker Https://covid-19.sledilnik.org/stats 
infections in the care homes. ${ }^{7}$ The identity of numbers is even more obvious in the case of mortality statistics. In the municipalities where contaminated care homes are situated there were 90 fatal cases or $86.54 \%$ of all fatal outcomes in the country. If we exclude Ljubljana municipality,

7 In some municipalities (Naklo, Šmarje, Ljutomer) the count of confirmed infections is even fewer than in the care homes. Maybe some residents have a permanent address in other municipality, or the infection has been recorded elsewhere (e.g. the municipality of the hospital). Metlika and Horjul also have only two more cases in the municipality than it was recorded in the old age home. By common sense we could expect quite the opposite - that, like in Ljubljana, there would be a higher rate of $C I$ in the environment than in a care home itself. This indicates, either that in these environments the tests have been performed almost only in old age homes, or that the virus was hardly spreading in the environment. However, also in Ljubljana the cases detected in the care home in Bokalci present almost a tenth (7.87\%) all detected cases. there were 79 such cases, still more than three quarters (75.96) of all deaths. If we add few cases from Ljubljana (Bokalci home) we would arrive at 83 deceased in the old age homes which is $79,81 \%$ of deceased in the country.

The geographical representation of confirmed infections, particularly of mortality, seems to be a euphemism, representing really the care homes rather than municipalities. However, this gaze illustrates that this is an institutional epidemic or epidemic that requires a death toll, almost exclusively in institutions.

The review of available statistics can therefore be concluded by stating that as many as four fifths of deaths were related to old age homes. It can be maintained that it is an infection or on epidemic, which is predominantly or at least largely institutional.

Upon this finding we can assume:

Table 3: Number of confirmed infections by municipalities

\begin{tabular}{|l|r|r|r|r|r|}
\hline municipality & CI & Deceased & $\begin{array}{r}\text { CI \% in- } \\
\text { habitants }\end{array}$ & $\begin{array}{r}\text { deceased \% } \\
\text { population }\end{array}$ & $\begin{array}{r}\text { mortality } \\
\text { of CI }\end{array}$ \\
\hline & & & & & \\
\hline Šmarje & 174 & 37 & 1,693 & 0,360 & 21,3 \\
\hline Ljutomer & 135 & 19 & 1,198 & 0,169 & 14,1 \\
\hline Metlika & 73 & 16 & 0,869 & 0,191 & 21,9 \\
\hline Horjul & 28 & 6 & 0,923 & 0,198 & 21,4 \\
\hline Ljubljana & 254 & 11 & 0,086 & 0,004 & 4,3 \\
\hline Naklo & 3 & 1 & 0,056 & 0,019 & 33,3 \\
\hline Sum of respective municipalities & $\mathbf{6 6 7}$ & $\mathbf{9 0}$ & & & 13,49 \\
\hline Ljubljana excluded & 413 & 79 & & & 19,13 \\
\hline Total & 1465 & 103 & & & 7,03 \\
\hline Difference & 798 & 13 & & & 1,63 \\
\hline
\end{tabular}

Source: COVID-19 tracker Https://covid-19.sledilnik.org/stats 
- Either that the residents of old age homes are less resilient,

- Or that the old age homes are a factor of wider and faster contamination.

The truth is probably somewhere in-between the hypothesis of the institutionalism as a momentum of spreading infection and of the old age as factor of mortality. The dynamics of spreading the infection in a handful of care homes indicates that institutional moment was, at least in the observed period, probably a more potent factor.

\section{Institutions as (most powerful) risk factor - how the characteristics of care homes contribute to the spread of the infection}

That institutions are the ideal agar - a culture media - for diseases and infections has been clear for a long time. Even without data and research, one can see that in large concentrations of people, there is a significantly higher chance of contact and transmission of an infection. We also know diseases, which people catch only in places of this kind (legionella, CA-MRSA) or diseases that are primarily resident in institutions (e.g. rotavirus in old age homes and kindergartens). Corona disease does not appear as one of them, but what the numbers tell is not far from it. It is probably about a combination of two characteristics of an epidemics - a transmission in society at large, which gets concentrated in the institutions. Therefore, in the case of the epidemic of new corona virus, institutions are the node of transmission and also, given the mortality rates, its last stop.

Such institutions have, inter alia, two characteristics. The first is segregation, the second congregation. They are relatively separate from their environment, sometimes even isolated, concurrently there are big numbers of people of a distinct category placed in them. ${ }^{8}$ In other words, we could say that it is difficult for the virus to get into the institution, but when it is there, there are ample opportunities for its reproduction and transmission. In this context, such institutions, in the case of COVID, especially old age homes, are like time bombs, waiting for a random discharge.

\section{Transmitters and whisperers vs. passive victims}

Although care homes are relatively isolated, they are, in contrast with, for instance, an isolated mountain village, which can be quite self-subsistent, highly dependent on the environment; even maximum-security prisons cannot prevent entry of the most forbidden matters (drugs, weapons). An entry of the virus is not, of course, a deliberate act, but a slip, an unfortunate event, a probability (and almost certainty, as it turned out) since even in the case of visits ban, the staff and

For a description and analysis of total institutions, see the classic Goffman's work Asylums (1961) as well as the author's work on the subject (e.g. Flaker, 1998, 2015). For the treatment of the old age homes as total institutions see (Mali, 2008). 
suppliers of various goods enter the home. Restrictive measures and strict controls can reduce the probability of entry, but cannot prevent it totally.

Given that home visits were banned very soon and the residents were not allowed to leave the premises, import of the virus into the care homes can be attributed to staff, who are more mobile and have multiple contacts with the environment. ${ }^{9}$ Given that the last entry of the virus in the observed period was recorded on $1^{\text {st }}$ April, we can assume that the cessation of entry of the virus into the care homes was more likely a result of stricter measures outside (restriction of movement between municipalities, etc.) than measures in the care homes themselves.

However, if they were able to limit contacts between residents (e.g. no sitting together in the hall, group activities, mutual visits etc.), the movement of staff and their contact with several residents could not be completely restricted. In this sense, the staff are prone transmitters of the virus. ${ }^{10}$ A resident, also in case of restrictions, has contact with two or three employees at least, most probably more

According to the statistical records, the infection was first detected with staff in three care homes and with residents in the other three. However, this does not tell us about the agent of the entry, which was probably in all cases the staff, perhaps someone else, least of all the residents.

10 Goffman (1961) describes the mechanisms of (illicit) transportation of goods and transmission of information in total institutions. Among important channels of this activity are staff, who have ample opportunities of movement between the wards and between the institution and the outside world. (about five). On the other hand, a caregiver has contact with the residents of the entire department where she or he serves.

Although, we could presume that employees are more exposed, the numbers suggest otherwise. In five homes ${ }^{11}$ there is a constant difference of 10 to 15 percent between the level of confirmed contamination of staff and residents. This difference can be explained by the fact that all staff are not exposed to contact with other staff (administration, some would work from home); but also by the more numerous and intense contacts of staff with residents in the process of care.

However, the difference in exposure can also be interpreted with a different degree of carefulness and attentiveness. Some may be more careful, pay more attention to hygiene, distance, etc., while others are less attentive. This depends partly on the atmosphere and attitudes of the institution, its mentality, and partly on the personal stance of the individual employee. In both cases, in addition to carelessness as a personality trait or collective sloppiness, which can be also a result of the institution's setting, the relationship with the residents is an important contingency.

Objectification of the residents is namely one of the common characteristics of total institutions. Institutional care is organised according to the principles of industrial, mass production. Such an attitude and relationships are in fact a

11 The sixth one was a small one with very few confirmed infections. 
bureaucratic clutch, but functions also as a defence mechanism against the anxiety an attachment to a resident may cause (Menzies, 1988), and is also a result of focusing on physical care and performing "technical" tasks, which is a common orientation of the care institutions. All this often amounts to the staff perceiving and handling residents as objects of their work (care) and less as people with their wishes, worries, relationships and personal histories.

In the conditions epidemic, increased isolation (incarceration), fewer visits, etc. such an attitude with some staff or in some institutions may intensify. In particular, this may become an "agar" for breeding of an "egotistical" attitude or a careless attitude to the epidemic and virus transmission. There are two purely human, ethical safeguards for caution of safety regarding the transmission. I can be careful not to infect myself, but if I do not care about myself - because I am young or because I've given up on fate or because the social life or economic gain is more important to me than health - there is a "safety valve" of caring for well-being of another. "I will be careful not to infect other people, important people to me." - e.g. a grandson will not hang out with friends because he visits his grandmother, or on the contrary, he will not visit his grandmother because he has been hanging out with his peers. ${ }^{12}$

12 Institutionalisation by placing a person under institutional authority and guardianship absolves from precisely this, second responsibility and solidarity.
The more staff define their work as working with objects rather than with people, the greater the chance that staff will not see the other as a person; they will not care whether they wear a mask in their presence or whether they will observe the instructions or not. The position and power of the residents, being dependent on the staff, is such that it is difficult for residents to point out staff's faults and inconsistencies, and even if they do, it is not very likely that the staff will listen. ${ }^{13}$

The available data show that the care homes, in which the virus has entered, differ in the degree of contamination spread. In two homes, it reached almost two-thirds of residents, which is, coincidentally, the value, which is assumed to represent the "herd immunity", in following two homes one-third or a fifth of residents were contracted, and in two homes the values were of one-digit percentages. It can therefore be said that in the first case the virus spread relatively uncontrollably, in two cases it was stopped at some stage and immediately held at bay in the last two homes (see Table 2 above). This could have been a result of a set of circumstances, or it could have been an effect of an adequate

13 Goffman (ibidem) describes the underlife of total institutions. Both residents and staff of an establishment shall participate in various unauthorised, unwanted or officially unforeseen activities which allow the deviation from the prescribed roles. Shunning and dodging is the way of life in such institutions. Therefore, we cannot be surprised that some workers will not follow rules, instructions or other measures. They will make their work easier, brighten their routines, express themselves and spend the day. 
response (even maybe unintentionally) - this we do not learn from the figures. However, this needs to be investigated, precisely for the better directions in the future (second wave of epidemic).

In the institutions with more two or more bedded rooms the possibilities of transmission are greater (due to contacts between roommates, increased frequency of staff coming and too little distance between the beds). Self-isolation in the care homes is practically impossible, even when in some homes the residents of single bedrooms were confined to their rooms. In the table below, we see that homes where infections have occurred, with the exception of Naklo, are well below the national average in terms of number of one-bed rooms (national average not being favourable itself - in some countries, like Austria, the standard is a single room for a long time), these had more multiple bed rooms than Slovenian care homes on average.

This feature indicates that the contaminated care homes were not the establishments which have invested into the privacy of residents and into personalisation of the services.

Table 4: Proportions of rooms with single and multiple beds in social care homes

\begin{tabular}{|l|l|r|r|r|r|r|r|r|r|r|}
\hline & Type & $\begin{array}{r}\text { No. } \\
\text { places }\end{array}$ & $\begin{array}{r}\text { No. } \\
\text { rooms }\end{array}$ & $\begin{array}{r}\text { Res./ } \\
\text { room }\end{array}$ & 1 bed & 2 bed & 3 bed & $\begin{array}{r}4 \\
\text { bed }\end{array}$ & $\begin{array}{r}5 \\
\text { bed }\end{array}$ & $\begin{array}{r}\text { apart- } \\
\text { ment }\end{array}$ \\
\hline $\begin{array}{l}\text { Šmarje } \\
\text { pri Jelšah }\end{array}$ & Public & 214 & 118 & 1,81 & 36 & 68 & 14 & & \\
\hline percent & & & & & $\mathbf{3 0 , 5 1}$ & $\mathbf{5 7 , 6 3}$ & $\mathbf{1 1 , 8 6}$ & & & \\
\hline Naklo & Public & 46 & 38 & 1,21 & 30 & 8 & & & & \\
\hline percent & & & & & $\mathbf{7 8 , 9 5}$ & $\mathbf{2 1 , 0 5}$ & & & & \\
\hline Horjul & Private & 155 & 92 & 1,68 & 32 & 57 & 3 & & & \\
\hline percent & & & & & $\mathbf{3 4 , 7 8}$ & $\mathbf{6 1 , 9 6}$ & $\mathbf{3 , 2 6}$ & & & \\
\hline Bokalci & Public & 378 & 192 & 1,97 & 56 & 86 & 50 & & & \\
\hline percent & & & & & $\mathbf{2 9 , 1 7}$ & $\mathbf{4 4 , 7 9}$ & $\mathbf{2 6 , 0 4}$ & & & \\
\hline Ljutomer & Public & 172 & 103 & 1,67 & 36 & 61 & 6 & & \\
\hline percent & & & & & $\mathbf{3 4 , 9 5}$ & $\mathbf{5 9 , 2 2}$ & $\mathbf{5 , 8 3}$ & & & \\
\hline Metlika & Public & 172 & 94 & 1,83 & 22 & 66 & 6 & & & \\
\hline percent & & & & & $\mathbf{2 3 , 4 0}$ & $\mathbf{7 0 , 2 1}$ & $\mathbf{6 , 3 8}$ & & & \\
\hline $\begin{array}{l}\text { Total } \\
\text { Slovenia }\end{array}$ & & 18.962 & 11.580 & 1,69 & 5.206 & 5.384 & 595 & 358 & 35 & \\
\hline percent & & & & & $\mathbf{4 4 , 9 1}$ & $\mathbf{4 6 , 4 5}$ & $\mathbf{5 , 1 3}$ & $\mathbf{3 , 0 9}$ & $\mathbf{0 , 3 0}$ & $\mathbf{0 , 1 2}$ \\
\hline
\end{tabular}

Source: SSVZS - KAPACITETE - DOMOVI ZA STAREJŠE IN POSEBNI SVZ; accessible at: http://www.ssz-slo.si/wp-content/uploads/Register-kapacitet-1.1.2020.pdf 16.5. 2020 


\section{Totality of the institution - the greatest risk factor}

Discussing the available data, we were able to identify certain factors that have likely contributed to the spread of the epidemic in the old age homes. We have seen that the size of an institution, although not crucial, may be important - the contaminated homes were on average of a larger kind. We have seen that these were in most cases rural homes. ${ }^{14}$ We have also seen that contaminated facilities have more multiple beds rooms, which besides greater possibility of virus transmission indicates lack of orientation towards personalisation of the provision. ${ }^{15}$

14 There is no obvious explanation for this hypothesis. Perhaps the periphery means an even greater degree of feeling of segregation, otherwise characteristic of total institutions, "to be out of sight (of society at large)." It could be also a peripheral "mind-set", often typical of the countryside, namely that 'this (epidemic) is happening somewhere else - in China, Italy, Ljubljana, or perhaps even in a neighbouring municipality, but not with us.' Such 'ostrich' tactic is a feature of total institutions too, in which a blind-eye or even disdain for what is happening outside is embedded. At the same time, there are also fears of incidents, which, according to established practice, are preferably handled in total institutions in a way to conceal them, which is more possible in a secluded establishment than outside. "A face-saving" concealing of the infection in old age homes has been reported in some homes in Italy.

15 These homes do not stand out for the innovation or introduction of personalised services and mechanisms of empowering of residents (Mali et al., 2018). Also, according to the statistics of the Association of the Social Care Homes, contaminated homes have but little offer beyond classical institutional care. Day care is provided in only three of the six homes, and only for a relatively
However, the most obvious and also controversial hypothesis (or explanation) is that the care homes are total institutions - not only by the virtue of intense concentration of people, but also with a characteristic atmosphere, perception of people as objects, imbalanced relationships between staff and residents and the lack of power of the latter. This might significantly facilitate the spread of infections. Additionally, the employees are carriers of infections, while residents are recipients and victims it (higher infection rates, more severe consequences). However, we had to reject the hypothesis that has been circulating, which may be true in other countries, that private homes are at a higher risk of spreading infections, even if this risk exists in principle, as private homes need to take greater care of the "economics" of the business. ${ }^{16}$

The size, type of institution, orientation, atmosphere, number of single rooms, staff-resident relations, as well as user strength and management style, are factors

small number of users (Šmarje 9, Ljutomer 8 and Bokalci 6 day visitors). The care home in Ljutomer has seven protected apartments, home help is provided by facilities in Šmarje and Metlika, but only for one user.

16 In Slovenia, private homes are formally not for profit, yet they still look for it in various sideways. In the countries where care for profit is allowed, the impetus of earning on the account of residents is more pressing, since the profit comes first and only then people. So even if our data do not confirm such a hypothesis, it must not be dismissed as irrelevant in the future. After all, fortunately, the time of the first wave of epidemic was short enough for all its possible implications for the functioning of the institutions to show and would be demonstrated over a longer period. 
that very clearly impact the spread of the virus through the establishment, but have less influence on its entry. If these are key issues for spread of infection, they are more or less random or indirect for its entry (e.g. larger institutions have more necessary contacts with the environment and therefore more possibility of the virus entry, more or less personal and responsible attitude towards residents may also be meaningful in attentiveness on the intake of things into the facility and to their own behaviour outside the home and vigilance on their own contamination). With all these possible effects, however, we can still conclude that virus entry is more or less a random event that the care homes, in which this happened, it was more of an accident than some wrongdoing. An entry of the virus to institutions is inevitable, even more so in Slovenia, which is at the top by the rate of institutionalisation (number of residents of institutions per population) (Huber et al., 2009), and this is also reflected in international statistics on deaths in social care homes where the number of deaths in Slovenia exceeds by as much as $20 \%$, the highest ranked country. ${ }^{17}$

An old age activist Biserka Meden (2020) provides on her Facebook page data for a few European countries published by the LSE (London School of Economics). Compared to our $80 \%$, the Covid-19 related mortality in institutions is in Ireland is 60\%, in France 51\%, in Sweden 45\%, Portugal 40\%, In Germany 36\%, In Denmark 33\% and Hungary $19 \%$.

\section{Community care - the security provider}

The most significant and common factor of fatal infections were - on the account of concentration of people and their internal structure and functioning - the institutions. This fact was circumvented since the impression of no real alternatives to the institutional care being available. But they are, and the cardinal sin of the last decades committed by the policy makers was that Slovenia has never really embarked on deinstitutionalisation and failed to introduce the long-term care to replace institutional care in a quality way.

Of course, the long-term care project is, to a large extent, a deinstitutionalisation effort - it is meant to replace institutional care with intensive care where people live, in the community. Yet, in Slovenia, long-term care has recently, especially in corona debates, become the synonym for institutional care: "The area of long-term care has long been neglected in Slovenia. Staffing hardship, outdated norms, insufficient space capacity [in care homes]. Then there is the virus, and with it, an initial lack of protective equipment, topped by sometimes contradictory instructions, lists Jasna Cajnko, director of the care home in Tezno." (Žorž, Bratina, Pollak, Ivanovič, \& Štravs, 2020). Such perspective needs to be reversed and long-term care should be seen as an alternative to the institutional care.

The victims of the virus in Slovenia in the first wave were almost exclusively old people, over three-quarters of victims 
were residents of old age homes. We could settle for an explanation that residents in the care homes are sicker, more vulnerable, which in turn results in a greater mortality. This is partly true. However, there are at least twice as many potential beneficiaries of long-term care outside the institutions, many of them who are comparable in age and health to those in their homes. Against this background, even taking into account the 'biased sample' (reduced visibility and observability or discernibility in the community), the mortality rate in the community should have been higher - according to a very flat estimate, the mortality rate outside in the community should be at least equal in not greater. Being old is a precondition and not a reason of the fatal outcome. Data show that the institutionalisation is the necessary clause, which in combination with the first leads to infection and death.

With a closer look, it is clear that alternatives to institutional care imply less risk. People who need long-term care and who are not in institutions receive domestic or family care, home care services or personal assistance. ${ }^{18}$ In all these forms of community care it is possible, in such an emergency situation, to, without much-a-do, reduce contacts to a desired minimum, comparable to self-isolation

\footnotetext{
18 Besides these forms of community-care, there are possibilities of small group homes, protected housing and a whole series of otherwise less established forms of care (accommodation in another family, mutual and neighbourhood help, self-organisation of care, personal service packages, etc.).
}

in younger groups of population, and, of course, below the minimum possible in the institutions.

In the case of personal assistance, for instance, the care provider is one and the same person, similarly in case of home or family care. In such cases, even if a person is being cared for by few people, the number of carers can be adjusted and reduced without significant and institution-comparable problems. It is also easier to regulate unnecessary contacts and keep them at bay..$^{19} \mathrm{~A}$ more personal approach, as well as more autonomous work, also encourages greater accountability, attention and consideration of the user, who also has more power to act for his or her interest and benefit. In short, self-isolation is a much more achievable ideal in the community than in an institution.

This was also practically demonstrated during the epidemic. Group quarantines proved to be more of a risk enhancing than reducing. In some total institutions, large proportions of residents - from psychiatric hospitals, from prisons - were discharged, released. This did not happen in old age homes.

\footnotetext{
19 This was done, for example, in some home care services. They restricted their service to the most urgent situations and urgent tasks. A reduction to such a degree is simply impossible in an institution, which needs to be 'running'in its basic functions (cooking, cleaning, and attending). In a home care situation the necessity can be assessed, and urgency applied - e.g. somebody can cook, but cannot do the shopping. Plus, in the situation of the lockdown-people working from home - there was more assistance available where people live. Which could not be used in the institutions.
} 
The care homes have, in the initial stage of epidemics, in fact offered to the residents an option of returning home or to their relatives, if they would have wished so or had had such an opportunity. Despite obvious advantages regarding the safety, only a handful of residents have opted for such a solution -41 residents of old homes and a further 210 from institutions for people with intellectual disabilities (Pihlar, 2020b). This in sum represents a little more than one percent of residents of all social care institutions, but only two percent per million residents of old homes. The reason for such a meagre response was that the conditions of discharge were impossible. One would need to continue to pay (out the pocket) the care home fee (only the meals were exempted), the care allowance would also remain with the institution. One could not have returned to the institution until the end of the epidemic, and there was a real threat that one would lose the place in the facility. ${ }^{20}$ The main missing link, however, was that there was no substitute service or support necessary for a resettlement. The whole system is indeed set institutionally, there is a little capacity outside that would support resettlement nor was there interest or will, perhaps no ideas to establish it. ${ }^{21}$

20 In the period after the end of the first wave (22 nd May), we had the opportunity to read dramatic story on this (Lesjak Tušek, 2020), which described the situation and the trouble of returning home. Soon after the publication of the story the authorities showed intention to reimburse some of these costs (La. Da., 2020; Pihlar, 2020a).

21 Having no idea about what to do next was also a feature of discharge from psychiatric institutions
However, there were ideas of translocate the infected residents into the hospitals.

Instead of discussing what to do with the institutions the main controversy was about in which institution an old person who has contracted the disease should be tended (parked) in (Jager, 2020a; Pribac, 2020; Žorž, Bratina, Pollak, Ivanovič, \& Štravs, 2020; Kovač, 2020). It does, however, address important ethical issues, including the issue of ageism, abandonment of aid, decision-making about the lives and deaths of old people without their knowledge, let alone consent. It also drew attention to some of the characteristics of the institutions we are discussing here (concentration of people, retention of people in institutions or advertently preventing them of returning home as a means of self-isolation, etc.). However, the shortcomings of old age homes were reduced to lack of equipment, lack of expertise, lack of premises and staff, etc. In this, however legitimate and important debate, it transfers the centre of gravity of the issue from one institution to another, from the question of total institution and institutionalisation to the question of what

and prisons. However, this ad hoc deinstitutionalisation was possible because the discharged did not need much actual care (or in case of prisons, "need" control). However, a certain number of people, especially those accustomed to visiting hospitals, have nevertheless suffered deprivation and distress, as community services for homeless and mental health have been shut down because of the epidemics. Sometimes the opposite of what should be done has happened-instead of shutting down the institutions and significantly strengthening community services (especially those providing home care) the latter have closed their doors. 
the type of institution is more suitable or to the advantages and disadvantages of one institution compared to another. ${ }^{22}$

Perhaps it might have been better for residents to be transferred to hospitals, but it would also certainly be better if the care homes were strengthened during the epidemic with specialists in the medical and health professions, supplied with more protective means (more and better masks, protective suits, etc.) and treatment equipment (oxygen, respirators). It would be even better, though, if all this was made possible at home or in some other form home-like care facility that enables self-isolation (e.g. emergency protected housing, etc.).

A transfer to the hospital might for many be a passage "from bad to worse." Renowned English epidemiologist Tom Jefferson, working in Italy, notes that the departure of an old person to hospital is almost certain death sentence (Sajovic, 2020). Probably because hospitals are comparably more dangerous places, but also because an old person is more vulnerable when being relocated. Moreover, he advocates not only for home care, but

22 On some level, it is also about transferring responsibilities and also of the work-load. In this handing over of "hot potatoes", two types of "racism" have surfaced. Abandoning aid to old people - "ageism" and fear and unwillingness to help the infected - in the desire to transfer the infected to hospitals and in the opposition to this by the hospitals. In both cases, however, the authorities tolerated such racism - as they do in other cases of racism, intolerance and hate speech. also for home treatment, since modern technology allows for it.

The self-isolation is the most effective tool of holding the epidemic at bay, but it is, from the social justice perspective also a luxury. Those on the extreme social margin - on one side the residents of social institutions or the homeless on the other - neither can afford it since they do not have a home of their own to take refuge in. In the case of epidemics, this was much more fatal issue for the residents of the old age homes.

\section{Humanity is a protecting factor - need for deinstitutionalisation}

It can be concluded that institutions for the old people were the very key pitch of the epidemic. In comparison with the whole agitation of the epidemics it was rather neglected and overlooked. Health, public health, were at the forefront - the social care figured just as phantom appendix to these. The numbers tell a completely different story. Better action in this area could have prevented many infections and deaths. This is even more true for the future, as systemic measures are necessary to prevent the possibility of transmitting the infection in a better way.

These systemic changes are - deinstitutionalisation and the long-term care. These are not one-time measures that could be done overnight. However, it is possible to set up soon enough some mechanisms that will strengthen external, community services, allow for more transitions to the home environment, more 
self-isolation, etc. - above all, give more power and control and the possibility for one's own action of old people and other service users.

In terms of deinstitutionalisation, it is also necessary to stop the rhetorical repetition, the refrain of needing to build more institutions - this is being repeated all over again during the epidemic, despite the obvious negative impact and adverse consequences these institutions have demonstrated. It must be reiterated that we need a better community services and more potent network of the services on the ground, where people live - more home care, personal assistance, coordinated care, protected accommodation and more input into informal forms of care.

But it is possible to quickly amend or improve few things, at least to some extent, in the very institutions - to enable individualisation, personalisation of care, to maximise the power of residents in decision making on the services they receive. This is possible to some extent by introducing some key innovations such as personal planning, advocacy, key workers, empowerment of residents, congruent care, household units, etc. With those we can change the attitudes, atmosphere and status and roles of residents in the institutions - which is a value in itself and not merely an instrument of prevention of the contamination (Mali et al. 2018).

With the review of available data from the perspective of the total institution, we were able to identify with great certainty some of the issues indicating the institutional dimension of the epidemic
- that, although the corona virus is not, of course, a classic institutional infection or disease, it has some of such characteristics, that the old age homes were the main but overlooked moment - if not the infections, then of the fatal consequences, that this is a structural matter which could be prevented by deinstitutionalisation and a potent long-term care. But it is also about the attitude and approach. Institutional care dis-empowers already powerless residents, transforms them into objects, makes them seem less human and relegates the worries and troubles to the places out-of-sight - which in turn explode in the times of corona.

The corona virus epidemic therefore alerts not only on climate change, excessive consumerism, the problem of division of labour and other shortcomings of today's social make-up, but also, in what we wanted to fail to notice, right at the heart of the epidemic, in the mortality rates, discerns the sinisterness and inhumanity of the institutions have been created some two centuries ago for the weakest members of society. Like in other matters that have surfaced in the epidemic, there is an opportunity for something new, for a meaningful action, in this case this being literally a matter of life and death.

\section{Post scriptum}

As noted, the bulk of this text was written at the end of first wave of epidemics, hoping to learn some lessons and prevent some deaths. This, however, did not happen. In Slovenia, and some 
other countries institutions are still foci of contamination and mortality in the second wave. Even in some institutions that are earmarked for deinstitutionalisation and where there are resources available for the resettlement the corona has stopped the process, which should in turn be accelerated to prevent the disaster. For instance, the additional staff already hired was put on hold instead of supporting the overburdened existing staff, instead of rapid resettlement and dispersion of residents and staff (into bubbles) residents got even more locked and restrained. The available resources to acquire new premises in the community have frozen for whatsoever bureaucratic reasons - in many ways has corona strengthened the bureaucratic virus.

There was no strengthening of the community services nor incentives for domestic care - to return to home or relatives for those who have this opportunity nor personal planning and inventing new solutions for those who do not. Instead, the energy was spent in quite unproductive deliberations of the red and grey zones, how to impose tighter restrictions and control.

Not only the opportunities were missed to invent and arrange something new, to transform the institutions, the residents have found themselves in the "high secu- rity prisons" - they are kept from going out, the visits are banned or significantly reduced (some visitors vividly reminisce the prison conditions of one hour per week visit, in a special space, with an attendant etc.). The in-house services like physiotherapy, work therapy, support groups were considerably downsized and the rapport between care staff and residents deteriorated on the account of being perpetually closed, stressed and without meaningful contact with the outside world.

This had a disastrous effects on the residents - people with a mild dementia failed to recognise their close ones once they had chance to finally see them, residents with mobility issues got even more immobile and the residuum of movement diminished, with no visitors they ceased to expect their loved ones and without an outside world they got more and more enmeshed in the maze of institutional relationships, they have started to feel even more like objects, less like persons and many are giving up and developing what doctors would call depression (which in old age is path to die). It is obvious that corona is besides infecting and killing people taking yet another toll - the indirect ill effects might be as disastrous as the direct ones - but there is no count of these. 


\section{References}

Flaker, V. (1998). Odpiranje norosti: Vzpon in padec totalnih ustanov. Ljubljana: Založba */cf. Flaker, V. (2015). Deinstitutionalisation as a machine, Dialogue in Praxis, vol. 4., no. 1-2. Available at: http://dialogueinpraxis.fsd.uni-lj.si/index.php?id=5\&a=article\&aid=45

Goffman, E. (1961). Asylums, Doubleday, New York (Pelican edition 1968).

Jager, V. (2020a). So bili starostniki že vnaprej odpisani? (Je delež starostnikov, ki so umrli v domovih za starejše, tako izstopajoče visok zaradi seznamov odpisanih?). Mladina, $15^{\text {th }}$ May, 2020. Accessed 25 ${ }^{\text {th }}$ May 2020 at: https://www.mladina.si/198410/so-bili-starostniki-ze-vnaprej-odpisani/?fbclid=IwAR3xVmY6lW1JNNqytbcMugcngZcT5ZT_atRwhB_AiLHRRjvy4yq5CWSUIvs

Jager, V. (2020b). V domovih za starejše obstajajo seznami odpisani, ki ne smejo priti v bolnišnico. (Intervju z Dušanom Kebrom). Mladina 20, $15^{\text {th }}$ May 2020, pp. 39-42.

Kovač, V. (2020). Odločitev, da se bolne in okužene zadrži v domovih, je bila slaba in ima tragične posledice (Pri nas je umrlo 106 ljudi, od tega jih je bilo 86 oskrbovancev domov za starejše). TV Slovenija, 23 ${ }^{\text {rd }}$ May 2020, MMC RTV SLO. Accessed 24 $4^{\text {th }}$ May 2020 at: https://www.rtvslo.si/zdravje/novice/odlocitev-da-se-bolne-in-okuzene-zadrzi-vdomovih-je-bila-slaba-in-ima-tragicne-posledice $/ 524860$

La. Da. (2020). Sprejem novih oskrbovancev v domove za starejše možen s 25. majem? (Obeta se povračilo za svojce, ki so oskrbovance med epidemijo nastanili doma). MMC RTV $S L O, S T A, 20^{\text {th }}$ May 2020. Accessed $24^{\text {th }}$ May 2020 at: https://www.rtvslo.si/slovenija/ sprejem-novih-oskrbovancev-v-domove-za-starejse-mozen-s-25-majem/524512

Lesjak Tušek P. (2020). Socialnozdravstveni zavodi in covid-19: Bili so doma, a plačali za oskrbo v zavodu. Večer, $22^{\text {nd }}$ May 2020. Accessed 24 ${ }^{\text {th }}$ May 2020 at: https://www. vecer.com/socialnozdravstveni-zavodi-in-covid-19-bili-so-doma-a-placali-za-oskrbov-zavodu-10173216

Mali, J. (2008). Comparison of the characteristics of homes for older people in Slovenia with Goffman's concept of the total institution. European journal of social work, vol. 11 , no 4, str. 431-443.

Mali, J., Flaker, V., Urek, M., Rafaelič, A. (2018). Inovacije v dolgotrajni oskrbi : primer domov za stare ljudi. Ljubljana: Fakulteta za socialno delo.

Meden Marolt B. (2020). Facebook [post on topic of Covid mortality in old age homes 14 $4^{\text {th }}$ May]. Accessed 24 $4^{\text {th }}$ May at: https://www.facebook.com/photo. php?fbid=10220437749326559\&set $=$ a.4855946369296\&type $=1 \&$ theater

Menzies, L.I. (1988), Containing Anxiety in Institutions. London: Free Association Books. Pihlar, T. (2020). Katera številka o umrlih v bolnišnicah je prava? Dnevnik, $22^{\text {nd }}$ May 2020. Accessed 24 $4^{\text {th }}$ May 2020 at: https://www.dnevnik.si/1042929990/slovenija/ katera-stevilka-o-umrlih-v-bolnisnicah-je-prava.

Pihlar, T. (2020b). Domovi starejših: nad koronavirus tudi s praznimi posteljami. Dnevnik, Zdravje, $25^{\text {th }}$ May 2020. Accessed $25^{\text {th }}$ May at: https://www.dnevnik.si/1042930302/ slovenija/domovi-starejsih-nad-koronavirus-tudi-s-praznimi-posteljami-

Pribac, I. (2020). Smo res to storili? Mladina, 21/22. 5. 2020, str. 50-51.

Sajovic, K. (2020). Na tej točki karantena ni ravno smotrna - duh je že ušel iz stekleničke: Intervju z britanskim epidemiologom Tomom Jeffersonom. $1^{\text {st }}$ April 2020, Rim - MMC 
RTV SLO. Accessed 24 $4^{\text {th }}$ May 2020 at: https://www.rtvslo.si/zdravje/novi-koronavirus/ na-tej-tocki-karantena-ni-ravno-smotrna-duh-je-ze-usel-iz-steklenicke/519071?fbclid=IwAR0SprqgBhwo3wM4sHBIbkhNHKJRSIGDwJy-4ToLipnazcTXKpfRQvvIQYM. Huber, M., Rodrigues, R., Hoffmann, F., Marin, B., Gasior, K. (2009). Fact and Figures on Long - Term Care: Europe and North America. Vienna; European Centre for Social Welfare Policy and Research.

Žorž, M., Bratina, Š., Pollak, T., Ivanovič, U., Štravs, A. (2020). Prvi val domove za starejše ujel nepripravljene, zdaj je čas za odpravo napak. Domovi za starejše: Cone neudobja. Radio Slovenija, $17^{\text {th }}$ May 2020, MMC RTV SLO, Radio Slovenija. Accessed 24 ${ }^{\text {th }}$ May 2020 at: https:/www.rtvslo.si/slovenija/ prvi-val-domove-za-starejse-ujel-nepripravljene-zdaj-je-cas-za-odpravo-napak/524085 